\title{
Several Fruit Characteristics of Rosa sp. Genotypes from the Northeastern Region of Romania
}

\author{
Craita Maria ROSU ${ }^{1 *}$, Ciprian MANZU², Zenovia OLTEANU², Lacramioara OPRICA² \\ Adrian OPREA ${ }^{1}$, Elena CIORNEA², Maria Magdalena ZAMFIRACHE² \\ ${ }^{1}$ NIRDBS-Institute of Biological Research, Department of Cell Biology and Microbiology, 47 Lascar \\ Catargiu Street, 700 107, Iasi, Romania; craita2002@yahoo.com ( ${ }^{*}$ corresponding author) \\ 2 "Alexandru Ioan Cuza" University, Faculty of Biology, 20A Carol I Bdv, 700506, Iasi, Romania
}

\begin{abstract}
There is great evidence regarding the beneficial influence of rose hips on human and animal health. In this respect, fruits of native populations of Rosa spp. collected from the northeastern part of Romania (400-1060 m altitude) were assayed for nutritional and some morphological properties, in order to select the best genotypes. The results show a great quantitative variability of analyzed genotypes, regarding dimensions and biochemical indicators as follow: ascorbic acid: $866.91 \mathrm{mg} / 100 \mathrm{~g} \mathrm{fw}(R$. rubiginosa $), 615.98 \mathrm{mg} / 100 \mathrm{~g} \mathrm{fw}(R$. caesia); carotenes: $34.95 \mathrm{mg} / 100 \mathrm{~g} \mathrm{fw}(R$. subcanina), $24.64 \mathrm{mg} / 100 \mathrm{~g} \mathrm{fw}$ (R. nitidula); protein content: $0.47 \mathrm{~g} / 100 \mathrm{~g}$ fw $(R$. micrantha), $0.25 \mathrm{~g} / 100 \mathrm{~g} \mathrm{fw}$ (R. caesia); total sugars: $17.63 \mathrm{~g} / 100 \mathrm{~g} \mathrm{fw}(R$. andegavensis $), 11.55 \mathrm{~g} / 100 \mathrm{~g} \mathrm{fw}(R$. caryophyllacea). The fruits length, width and dry weight were: $25 \mathrm{~mm}(R$. canina), $12 \mathrm{~mm}(R$. micrantha), $16.5 \mathrm{~mm}(R$. corymbifera $), 8 \mathrm{~mm}(R$. micrantha $)$ and $25 \%$ dry weight ( $R$. rubiginosa), 38\% dry weight $(R$. nitidula), respectively. The present study demonstrates the existence of a rich rose germplasm source in north-east area, with good biotechnological fruit quality, which recommends them as functional foods according to their chemical contents ( $R$. rubiginosa, $R$. vosagiaca, $R$. subcanina, $R$. canina and $R$. caryophyllacea) and also as sources for natural colorants in food technology.
\end{abstract}

Keywords: ascorbic acid, carotenes, protein, rose hips, total sugars

\section{Introduction}

Rose hips are one of the richest fruits in vitamins (especially vitamin C) from Romania and can be found in the spontaneous flora in large quantities. These species hold a key position in the strategy of the sustainable culture and by their biotechnological valences they can offer valuable solutions to the economic, social and environmental problems. Some of the desirable qualities of fresh or preserved rose hips are; elevated levels of vitamin C, carotenes, sugar and dry weight, which recommends them as functional food and could justify the exploitation of these very rich natural sources of vitamins, based on their benefit to human health. From this point of view, documented studies exist, related with the effect of rose hips on reducing the risk of cardiovascular diseases (Ninomya et al., 2007) or different form of cancer (Karakaya and Kavas, 1999; Omenn $e t$ al., 1996; Olsson et al., 2004). Also, consumption of fresh or preserved rose hips induces an anti-inflammatory effect (Deliorman et al., 2007; Winter et al., 2005).

The great nutritive and medicinal value of native populations of Rosa spp. are derived mainly from their chemical composition in sugars, proteins, lipids, tannins, pectin, organic acids, amino acids, essential oils and minerals (Celik et al., 2009; Chai and Ding, 1995; Daels-Rakotoarison et al., 2002; Erdurak-Kiliç et al., 2005; Ercisli and Guleryuz,
2006; Hornero-Mendez and Minquez-Mosquera, 2000; Olsson et al., 2005; Razungles et al., 1989; Uglla et al., 2003).

Within Romanian flora there are known 29 spontaneous and subspontaneous species, and also 5 hybrids of Rosa L. genus. From those 29 species, only 16 were identified in the northeastern part of Romania (Oprea, 2005). Therefore, the proposed research focused towards selection of germplasm sources in the Northeast area of Romania, which has a high content in bioactive principles.

\section{Materials and methods}

\section{Sample collection and processing}

Samples of Rosa spp. were collected from altitudes between 400-1060 m, from the northeastern region of Romania. According to taxonomic criteria (Buia and Prodan, 1956; Ciocarlan, 2000; Klášterský, 1968; Oprea, 2005) 10 species were identified as follows: Rosa canina L. S. Str., $R$. subcanina (Christ) Vuk., $R$. corymbifera Borkh., $R$. nitidula Besser, $R$. vosagiaca N.H.F. Desp., $R$. caesia Sm., $R$. caryophyllacea Besser, $R$. micrantha Sm., $R$. rubiginosa L. and $R$. andegavensis Bastard.

The fruits were harvested at the fully ripe mature stage (late September and October) for two years consecutively and stored at $4^{\circ} \mathrm{C}$ till processing. For each genotype and 
204

collecting year, the average samples (3 replicates) were randomly chosen from 100 fruits, mixed in a blender and analyzed for the ascorbic acid, carotenes, total sugar, protein level and dry weight. The results were expressed as the two year average $( \pm S E)$ of a total of six selected replicates for each genotype of Rosa spp. (33 fruits/replicates).The total replicates number depends on number of analyzed genotypes.

\section{Biometrical data}

Fruit width $(\mathrm{mm})$ and length $(\mathrm{mm})$ measurements were done on 100 fruits for each genotype.

\section{Assay of ascorbic acid content}

The ascorbic acid content was estimated with 2, 6-dichlorophenol indophenol solution (Artenie and Tanase, 1981). Results were expressed as mg of ascorbic acid per $100 \mathrm{~g}$ fresh weight.

\section{Assay of carotene content}

Fruits (0.2-0.3 g) were homogenized with a mixture of anhydrous sodium sulphate and calcium oxide, to retain water and colored compounds, except carotenes (Artenie and Tanase, 1981). Also, anhydrous sodium carbonate was added to prevent carotene decomposition in an acid medium. The homogenized fresh samples were then extracted with acetone and petroleum ether. The absorbance of the extracts was measured at $450 \mathrm{~nm}$ using a spectrophotometer (UV-1700 PharmaSpec., Shimadzu, Japan) The carotene content was expressed as mg carotene per $100 \mathrm{~g}$ fresh weight.

\section{Assay of total sugar content}

The total sugars in rose hips $(0.3 \mathrm{~g})$ were determined as total reducing sugars using 3,5-dinitrosalycilic acid method (Miller, 2002). Absorbances of the samples and the standard $(30-300 \mu \mathrm{g} / \mathrm{ml}$ glucose solution) were measured at $500 \mathrm{~nm}$ with a spectrophotometer (UV-1700 PharmaSpec Shimadzu) using distilled water as blank. The total sugar concentration of the samples was expressed as $g$ glucose per $100 \mathrm{~g}$ fresh weight

\section{Assay of soluble protein content}

The soluble protein content in fruit samples was determined according to the Bradford (1976) procedure. The results were expressed as g protein per $100 \mathrm{~g}$ fresh weight.

\section{Dry weight}

The dry weight of the fruit flesh was gravimetrically determined after drying the fruits at $105^{\circ} \mathrm{C}$ to constant weight. The percent of dry weight in samples was calculated according to Boldor (1983).

\section{Results and discussion}

\section{Ascorbic acid content}

The data presented, as a preliminary study on nutritional value of rose hip from the northeastern region of Romania, shows that a high level of vitamin $\mathrm{C}$ content exists with maximum values of $866.91 \mathrm{mg} / 100 \mathrm{~g} \mathrm{fw}$ (Rosa rubiginosa) and $816.77 \mathrm{mg} / 100 \mathrm{~g} \mathrm{fw}$ (Rosa vosagiaca) (Tab. 1). The lowest value $(615 \mathrm{mg} / 100 \mathrm{~g} \mathrm{fw})$ was assayed in Rosa caesia. In analyzed samples, ascorbic acid contents varied more with the genotype and not with the altitude (Fig. 1). A great content variability was noted between the genotypes.

In the previous comparative studies, a great variability in vitamin $\mathrm{C}$ content of rose hips was also found. For example, ascorbic acid content of various species of Rosa from different regions of Turkey ranged between 106 and $2712 \mathrm{mg} / 100 \mathrm{~g} \mathrm{fw}$ (Demir and Ozcan, 2001; Ercisli and Esitken, 2004; Ercisli, 2007; Kazaz et al., 2009; Yoruk et al., 2008).

Comparatively, Saeed et al. (2008) found only $417 \mathrm{mg}$ ascorbic acid/100 $\mathrm{g}$ fw in the fully ripe Rosa canina fruits in Iran. For East-European Region, studies on rose hips have revealed a vitamin $\mathrm{C}$ content in a range of 629-967

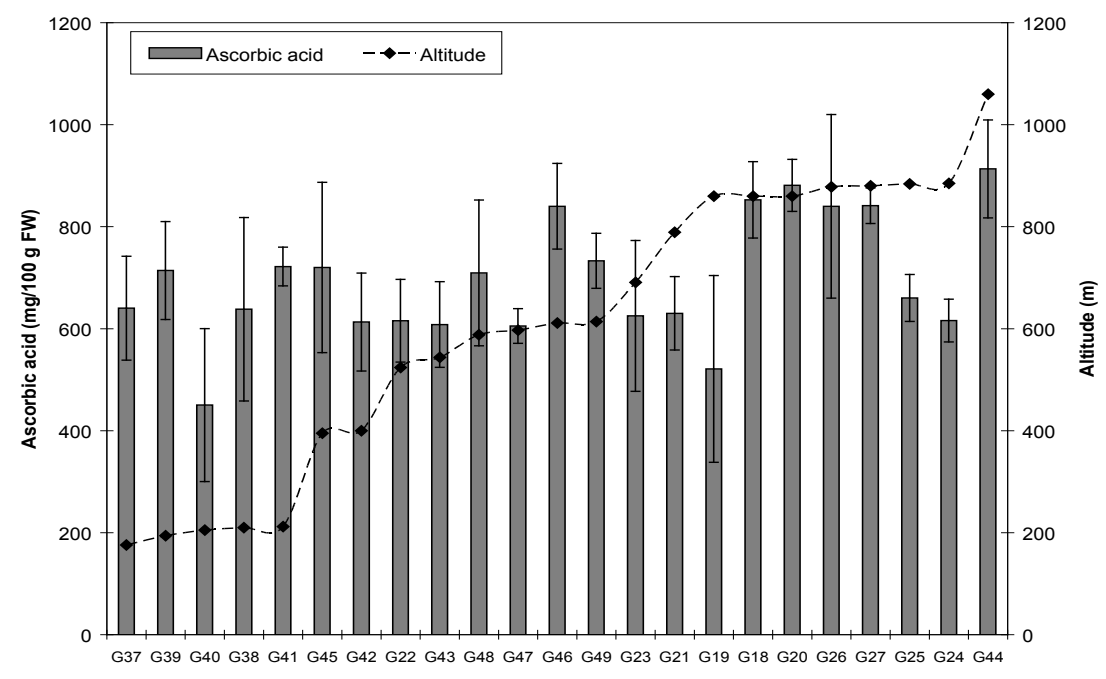

Fig. 1. Ascorbic acid content of Rosa sp. L. fruits at different genotypes and altitudes 


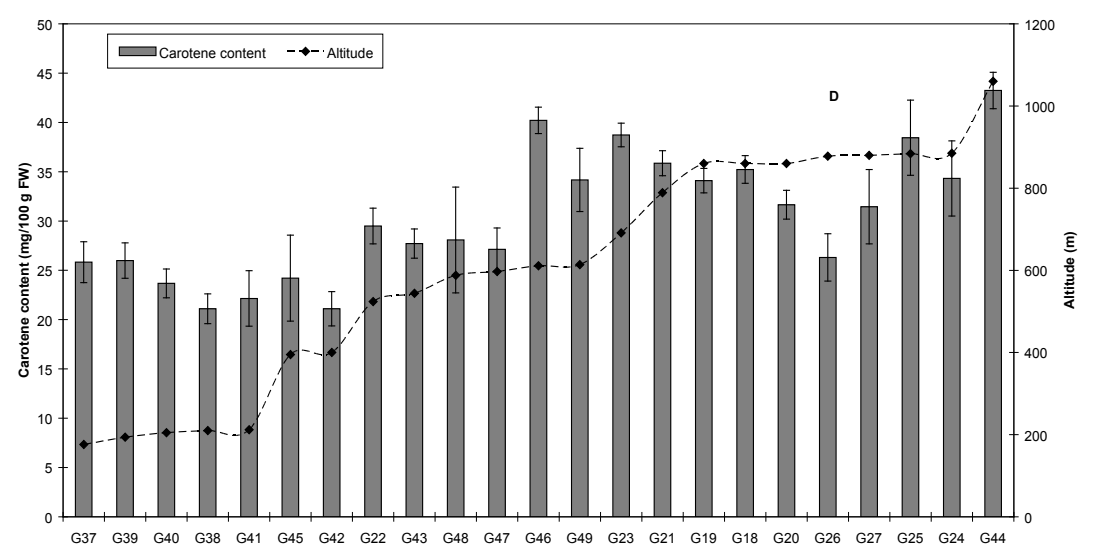

Fig. 2. Carotene content of Rosa sp. L. fruits at different genotypes and altitudes

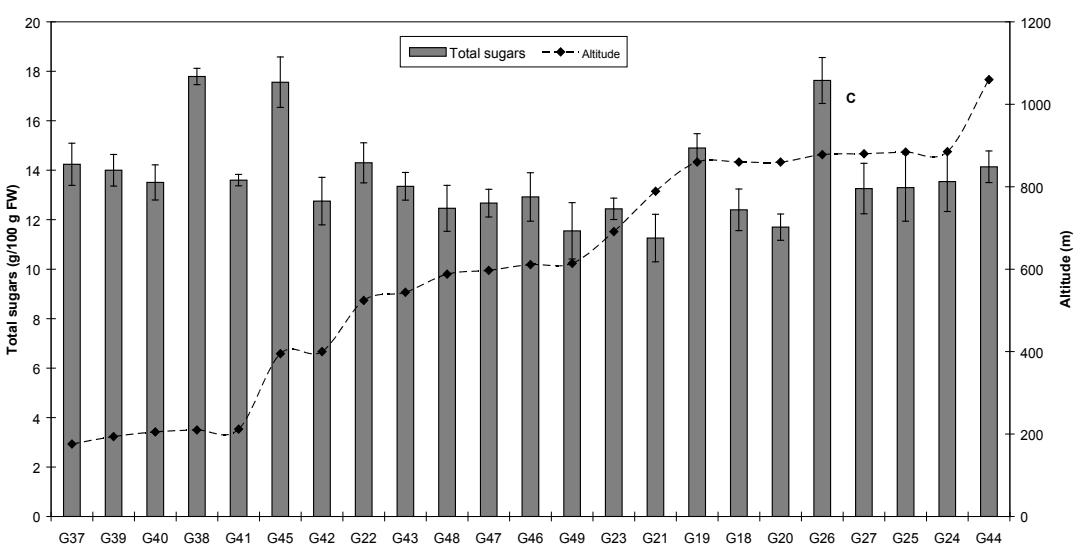

Fig. 3. Total sugars content of Rosa sp. L. fruits at different genotypes and altitudes

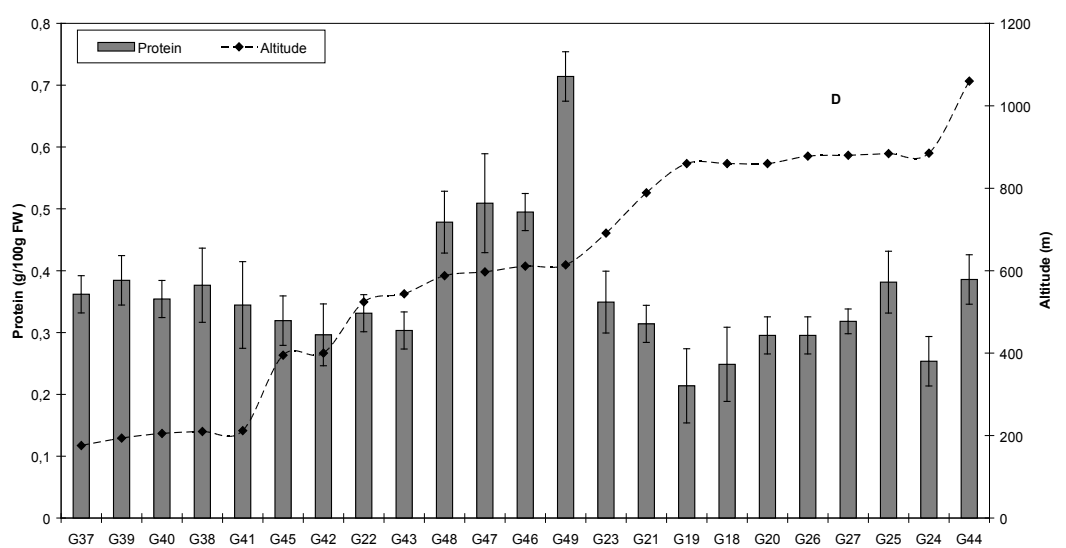

Fig. 4. Protein content of Rosa sp. L. fruits at different at different genotypes and altitudes

$\mathrm{mg} / 100 \mathrm{~g}$ (Halasova and Jicinska, 1988) and 211-417.5 $\mathrm{mg} / 100 \mathrm{~g}$ (Nojavan et al., 2008) in Rosa canina L. fruits.

\section{Carotene content}

The investigated rose hips contained a carotene content in a range of $34.95 \mathrm{mg} / 100 \mathrm{~g} \mathrm{fw}$ (Rosa subcanina (Christ) Vuk.) to $24.64 \mathrm{mg} / 100 \mathrm{~g} \mathrm{fw}$ (Rosa nitidula). For this indicator, the higher values were determined in the fruits growing after $700 \mathrm{~m}$ altitude in Suceava and Neamt districts (Tab.1 and Fig. 2).

Andersson (2009) found that carotenes content correspond to $48 \%$ of total carotenoids in the red-colored rose hips.
A high content was found by Hornero-Mendez and Minquez-Mosquera (2000) of $497.6 \mathrm{mg} / \mathrm{kg} \mathrm{dw}$ $(\beta$-carotene) and $391.9 \mathrm{mg} / \mathrm{kg} \mathrm{dw}$ (lycopene). This is also in agreement with other reports (Gao et al., 2000; Olsson et al., 2005). Olsson et al. (2004) concluded that rose hips have a high content of total carotenoids compared with other berries and small fruits.

\section{Total sugar content}

The total sugars content in the fruits of rose species was found to be in a range of $17.63 \mathrm{~g} / 100 \mathrm{~g} \mathrm{fw}$ (Rosa andegavensis) to $12.05 \mathrm{~g} / 100 \mathrm{~g} \mathrm{fw}$ (Rosa rubiginosa) (Tab. 1 and Fig. 3). 
Tab. 1. Nutritional value of Rosa sp. species identified in the northeastern region of Romania

\begin{tabular}{|c|c|c|c|c|}
\hline Species & $\begin{array}{c}\text { Ascorbic acid } \\
(\mathrm{mg} / 100 \mathrm{~g} \mathrm{fw})\end{array}$ & $\begin{array}{c}\text { Carotenes } \\
(\mathrm{mg} / 100 \mathrm{~g} \mathrm{fw})\end{array}$ & $\begin{array}{l}\text { Total sugars } \\
(\mathrm{g} / 100 \mathrm{~g} \mathrm{fw})\end{array}$ & $\begin{array}{c}\text { Protein } \\
(\mathrm{g} / 100 \mathrm{gfw})\end{array}$ \\
\hline R. rubiginosa L. $(\mathrm{n}=12)^{*}$ & $866.91 \pm 71.4^{* *}$ & $33.44 \pm 1.40$ & $12.05 \pm 0.84$ & $0.27 \pm 0.06$ \\
\hline R. canina L. S. Str. canina $(\mathrm{n}=42)$ & $643.38 \pm 138.4$ & $28.78 \pm 2.07$ & $13.28 \pm 0.85$ & $0.36 \pm 0.03$ \\
\hline R. subcanina (Christ) Vuk. $(\mathrm{n}=12)$ & $700.68 \pm 35.7$ & $34.95 \pm 3.77$ & $13.28 \pm 1.02$ & $0.35 \pm 0.03$ \\
\hline R. corymbifera Borkh. $(\mathrm{n}=24)$ & $614.54 \pm 120.11$ & $31.45 \pm 1.32$ & $14.62 \pm 0.33$ & $0.30 \pm 0.06$ \\
\hline R. vosagiaca N.H.F. Desp. $(\mathrm{n}=12)$ & $816.77 \pm 113.24$ & $33.72 \pm 8.45$ & $15.85 \pm 1.82$ & $0.35 \pm 0.03$ \\
\hline$R$. andegavensis Bastard $(\mathrm{n}=6)$ & $635.19 \pm 45.25$ & $26.31 \pm 2.40$ & $17.63 \pm 0.93$ & $0.29 \pm 0.03$ \\
\hline R. caesia $\operatorname{Sm} .(\mathrm{n}=6)$ & $615.98 \pm 96.43$ & $34.32 \pm 3.81$ & $13.54 \pm 1.36$ & $0.25 \pm 0.05$ \\
\hline R. nitidula Besser $(\mathrm{n}=12)$ & $663.57 \pm 45.32$ & $24.64 \pm 2.82$ & $13.13 \pm 0.23$ & $0.42 \pm 0.08$ \\
\hline R. micrantha Sm. $(\mathrm{n}=6)$ & $709.34 \pm 180.16$ & $28.08 \pm 5.36$ & $12.46 \pm 0.93$ & $0.47 \pm 0.05$ \\
\hline R. caryophyllacea Besser $(\mathrm{n}=6)$ & $733.18 \pm 123.43$ & $34.17 \pm 3.20$ & $11.55 \pm 1.14$ & $0.41 \pm 0.04$ \\
\hline
\end{tabular}

${ }^{*}$ Number of replication; ${ }^{* *}$ The values are the means of the replications $\pm S D$

The literature mentioned various contents in total sugars of fresh rose hips as follow: 13.34-17.14\% total soluble carbohydrates in Rosa canina fruits (Saeidi and Beygi, 2009) or 18-28\% (Uglla et al., 2005), expressed as glucose, sucrose and other sugars in Rosa spp. fruits. The results from literature, in a large broad of limits, as in case of total carotenoid content, result from different degrees of ripeness of fruits.

\section{Protein content}

Rose hips are not a very rich sources of proteins. The quantified protein level in the samples was small, with low variations, between $0.25 \mathrm{~g} / 100 \mathrm{~g} \mathrm{fw}$ (Rosa caesia) and 0.47 $\mathrm{g} / 100 \mathrm{~g} \mathrm{fw}$ (Rosa micrantha) (Tab. 1 and Fig. 3).

\section{Biometrical characteristics}

The dimension of the fruits varied in a range of 24.0$13.6 \mathrm{~mm}$ length, from Rosa canina to Rosa micrantha and between 16.2-8.8 mm width from Rosa corymbifera to Rosa micrantha. In case of dry weight of the fruits, an indicator with biotechnological importance, the registered values are usually more than $30 \%$. (Tab. 2).

The present results are in accordance with the literature in the field. For the Romanian topoclimateric conditions, some biometric characteristics of the rose hips has been noted (Buia and Prodan, 1956; Klášterský, 1968; Zanoschi in Zanoschi et al., 2000), as following:

- Rosa rubiginosa L.-hypanthium subglobose, ovoid or ellipsoid, 5-15 mm long.

Blossom: June-July.

Distribution in Romanian flora: sporadically, from plains to mountains.

- Rosa canina L. S. Str.-hypanthium globose, ovoid or ellipsoid, 15-20 mm long.

Blossom: May-June.

Distribution in Romanian flora: frequent, from plains to mountains, up to $1200(-1700) \mathrm{m}$ altitude.

- Rosa subcanina (Christ) Vuk. (Rosa vosagiaca subsp. subcanina (Christ) R. Keller)-hypanthium ovoid or globose, 10-20 mm long.
Blossom: May-June.

Distribution in Romanian flora: very rare, on plains.

- Rosa corymbifera Borkh. (Rosa dumetorum Thuill.)hypanthium globose to ovoid, $15-20 \mathrm{~mm}$.

Blossom: May-June.

Distribution in Romanian flora: relatively frequent, from plains up to mountains.

- Rosa vosagiaca N.H.F. Desp.-hypanthium globose (rarely ovoid), 15-20 mm long.

Blossom: May-June.

Distribution in Romanian flora: sporadically, from plains up to mountains.

- Rosa andegavensis Bastard-hypanthium globose to ellipsoid, 15-20 mm long.

Blossom: May-June.

Distribution in Romanian flora: very rare, on hills.

- Rosa caesia Sm. (Rosa coriifolia Fr.)-hypanthium globose to ovoid, the central one pyriform, up to $25 \mathrm{~mm}$ long.

Blossom: May-June.

Distribution in Romanian flora: sporadically, from plains to up mountains.

- Rosa nitidula Besser-hypanthium globose or ellipsoid, $15-20 \mathrm{~mm}$ long.

Blossom: May-June.

Distribution in Romanian flora: sporadically, on plains.

- Rosa micrantha Sm.-hypanthium globose or ellipsoid, $15-20 \mathrm{~mm}$ long.

Blossom: June.

Distribution in Romanian flora: sporadically, from plains up to mountains.

- Rosa caryophyllacea Besser-hypanthium subglobose to ellipsoid, $10 \mathrm{~mm}$ long.

Blossom: May-June.

Distribution in Romanian flora: sporadically, on hills.

The altitude, longitude and latitude of the growing area could have an influence upon the dimensions of the rose hips as following: length and width of fruits will be higher in the central areal of the growth than in marginal areas. 
Tab. 2. Fruit's length (mm), width ( $\mathrm{mm}$ ) and dry weight (\%) of some Rosa sp. genotypes

\begin{tabular}{|c|c|c|c|c|c|c|c|c|c|}
\hline \multirow{2}{*}{ Genotype /Species } & \multirow{2}{*}{ Altitude } & \multirow{2}{*}{ District } & \multicolumn{3}{|c|}{ Fruit length $(\mathrm{mm})$} & \multicolumn{3}{|c|}{ Fruit width (mm) } & \multirow{2}{*}{ Dry weight (\%) } \\
\hline & & & Mean & Min. & Max. & Mean & Min. & Max. & \\
\hline \multicolumn{10}{|c|}{ R. rubiginosa L. } \\
\hline G18-R. rubiginosa L. & 860 & Neamt & 17.7 & 13.8 & 22.6 & 13.2 & 10.6 & 16.6 & 28.47 \\
\hline G20-R. rubiginosa L. & 860 & Neamt & 19.9 & 15.1 & 24.9 & 12.1 & 9.8 & 14.3 & 32.08 \\
\hline \multicolumn{10}{|c|}{ R. canina L. S. Str. } \\
\hline G21-R. canina L. S. Str. & 789 & Neamt & 16.8 & 11.8 & 21.8 & 13.0 & 9.6 & 17.5 & 27.53 \\
\hline G22-R. canina L. S. Str. & 524 & Neamt & 20.7 & 14.9 & 26.1 & 14.8 & 11.9 & 17.3 & 31.85 \\
\hline G37-R. canina L. S. Str. & 176 & Botosani & 17.1 & 12.6 & 21.2 & 12.4 & 8.9 & 14.9 & 49.90 \\
\hline G39-R. canina L. S. Str. & 194 & Botosani & 19.8 & 11.4 & 29.0 & 13.7 & 11.5 & 16.3 & 42.91 \\
\hline G40-R. canina L. S. Str. & 205 & Botosani & 21.6 & 15.4 & 27.6 & 11.7 & 9.3 & 19.9 & 38.00 \\
\hline G42-R. canina L. S. Str. & 400 & Iasi & 24.0 & 17.8 & 30.9 & 14.8 & 11.7 & 18.8 & 34.71 \\
\hline G46-R. canina L. S. Str. & 611 & Suceava & 20.6 & 15.6 & 25.0 & 11.4 & 9.0 & 14.2 & 28.34 \\
\hline \multicolumn{10}{|c|}{ R. subcanina (Christ) Vuk. } \\
\hline G25-R. subcanina (Christ) Vuk. & 884 & Suceava & 19.3 & 15.6 & 22.1 & 12.8 & 9.6 & 14.9 & 32.93 \\
\hline G27-R. subcanina (Christ) Vuk. & 880 & Suceava & 22.0 & 15.4 & 27.7 & 14.1 & 11.4 & 17.5 & 33.00 \\
\hline \multicolumn{10}{|c|}{ R. corymbifera Borkh. } \\
\hline G19-R. corymbifera Borkh. & 860 & Neamt & 19.6 & 14.4 & 23.2 & 10.7 & 9.3 & 12.3 & 31.09 \\
\hline G23-R. corymbifera Borkh. & 691 & Suceava & 16.1 & 11.7 & 21.6 & 14.3 & 11.8 & 18.8 & 37.22 \\
\hline G28-R. corymbifera Borkh. & 770 & Suceava & 15.4 & 12.3 & 18.0 & 12.0 & 10.0 & 14.0 & 33.45 \\
\hline G38-R. corymbifera Borkh. & 210 & Botosani & 21.5 & 12.8 & 28.2 & 15.7 & 12.0 & 18.6 & 38.87 \\
\hline G43-R. corymbifera Borkh. & 544 & Suceava & 19.8 & 13.8 & 24.6 & 16.2 & 12.8 & 21.6 & 36.76 \\
\hline \multicolumn{10}{|c|}{$R$. vosagiaca N.H.F. Desp. } \\
\hline G44-R. vosagiaca N.H.F. Desp. & 1060 & Suceava & 18.0 & 14.0 & 21.7 & 12.3 & 9.9 & 15.0 & 32.59 \\
\hline G45-R. vosagiaca N.H.F. Desp. & 395 & Iasi & 23.0 & 16.9 & 28.2 & 12.5 & 10.0 & 15.3 & 33.28 \\
\hline \multicolumn{10}{|c|}{$R$. andegavensis Bastard } \\
\hline G26-R. andegavensis Bastard & 878 & Suceava & 18.9 & 13.2 & 24.3 & 14.2 & 10.9 & 17.8 & 31.76 \\
\hline \multicolumn{10}{|c|}{ R. caesia $\mathrm{Sm}}$. \\
\hline G24-R. caesia Sm. & 885 & Suceava & 19.6 & 15.2 & 25.0 & 16.1 & 13.5 & 19.3 & 29.33 \\
\hline \multicolumn{10}{|c|}{ R. nitidula Besser } \\
\hline G41-R. nitidula Besser & 212 & Botosani & 17.7 & 13.6 & 22.0 & 13.0 & 11.0 & 17.9 & 44.80 \\
\hline G47-R. nitidula Besser & 597 & Suceava & 18.2 & 12.7 & 23.7 & 11.6 & 7.7 & 13.7 & 42.12 \\
\hline \multicolumn{10}{|c|}{ R. micrantha Sm. } \\
\hline G48-R. micrantha Sm. & 588 & Suceava & 13.6 & 11.1 & 17.0 & 8.8 & 6.9 & 11.4 & 40.22 \\
\hline \multicolumn{10}{|c|}{ R. caryophyllacea Besser } \\
\hline G49-R. caryophyllacea Besser & 614 & Suceava & 12.6 & 9.4 & 16.0 & 13.0 & 10.6 & 15.2 & 37.34 \\
\hline
\end{tabular}

To conclude, the relevance of the biometric studies on the rose hips of various genotypes of Rosa spp. is only partially and always in concordance with the local conditions for the analyzed genotypes.

\section{Conclusions}

The present study of nutritional and biometric parameters of rose hips identified in the northeastern regions of Romania revealed the presence of very good natural sources of vitamin C, total sugars and carotene, which varies mostly with genotype and analyzed species. Only the carotene content appears to be positively correlated with altitude.
Due to a considerable variation in moisture levels of fruits, important quantitative differences of analyzed indicators have been noted, between genotypes, based on fresh weight comparison.

The best sources for the active components are Rosa rubiginosa L., $R$. subcanina (Christ) Vuk. and $R$. vosagiaca N.H.F. Desp., collected from Neamt and Suceava districts (> $800 \mathrm{~m}$ altitude).

\section{Acknowledgements}

This research is part of the project which is financially supported by the PNCD II (No.52142/2008)-National Research Program of Romania. 
208

\section{References}

Andersson SC (2009). Carotenoids, tocochromanols and chlorophylls in sea buckthorn berries (Hippophae rhamnoides) and rose hips (Rosa sp.). Swedish Univ. of Agricultural Sciences, Alnarp, PhD Diss. 60 p.

Artenie V, Tanase E (1981). Practicum of general biochemistry, Al. I. Cuza University Ed., Iasi, Romania.

Boldor O, Raianu O, Trifu M (1983). Plant physiology-practical approach. Didactical and Pedagogical Ed., Bucharest, Romania.

Bradford MM (1976). A rapid and sensitive method for the quantitation of microgram quantities of protein utilizing the principle of protein-Dye binding. Anal Biochem 72:248254.

Buia Al, Prodan I (1956). The Rosa L. genus, 708-835 p. In: Savulescu T. (Ed.). The R.P.R. flora IV., Edit. Acad. R.P.R, Bucharest, Romania.

Celik F, Kazankaya A, Ercisli S (2009). Fruit characteristics of some selected promising rose hip (Rosa spp.) genotypes from Van region of Turkey. Afr J Agric Res 4:236-240.

Chai JT, Ding ZH (1995). Nutrients composition of Rosa laevigata fruits. Sci Technol Food Ind 3:26-29.

Ciocarlan V (2009). Ilustrated flora of Romania. Pteridophyta et Spermatophyta. Ceres Ed., Bucharest, Romania.

Daels-Rakotoarison DA, Gressier B, Trotin F, Brunet C, Luycks M, Dine T, Bailleul F, Cazin M, Cazin JC (2002). Effects of Rosa canina fruit extracts on neutrophil respiratory burst. Phytoter Res 16:157-161.

Deliorman OD, Harteviollu A, Küpeli E, Yesilada E (2007). In vivo anti-inflammatory and antinociceptive activity of the crude extract and fractions from Rosa canina fruits. J Ethnopharmacol 112:394-400.

Demir F, Özcan M (2001). Chemical and technological properties of rose (Rosa canina L.) fruits grown wild in Turkey. J Food Eng 47:333-336.

Ercisli S, Esitken A (2004). Fruit characteristics of native rose hip (Rosa spp.) selections from the Erzurum province of Turkey. New Zeal J Crop Hort 32:51-53.

Ercisli S, Guleryuz M (2006). Fruit properties of promising rose hips (Rosa spp.) from the northeastern Anatolia Region of Turkey. Asian J Chem 18:239-242.

Ercisli S (2007). Chemical composition of fruits in some rose (Rosa spp.) species. Food Chem 104:1379-1384.

Gao X, Bjork L, Trajkovski V, Uglla M (2000). Evaluation of antioxidant activities of rose hip ethanol extracts in different test systems. J Sci Food Agr 80:2021-2027.

Halasova L, Jicinska D (1988). Amounts of ascorbic acid in the hip of Rosa species. Folia Geobot Phytotx 23:181-185.

Hornero-Mendez D, Minquez-Mosquera MI (2000). Carotenoid pigments in Rosa mosqueta hips, an alternative carotenoide source for foods. J Agric Food Chem 48:825-828.

Karakaya S, Kavas K (1999). Antimutagenic activities of some foods. J Sci Food Agr 79:237-242.

Kazaz S, Baydar H, Erbas S (2009). Variations in chemical compositions of Rosa damascena Mill. and Rosa canina L. fruits. Czech J Food Sci 27:178-184.
Klášterský I (1968). Rosa L., 25-32 p. In Tutin, TG (Ed.). Flora Europaea, II, Cambridge University Press.

Miller GL (2002). Use of dinitrosalycilic acid reagent for determination of reducing sugar. Anal Chem 31:426-428.

Ninomya K, Matsuda H, Kubo M, Morikawa T, Nishida N, Yoshikawa M (2007). Potent anti-obese principle from Rosa canina: structural requirements and mode of action of transtiliroside. Bioorg Med Chem Lett 17:3059-3064.

Olsson ME, Gustavsson KE, Andersson S, Nilsson Å, Duan $\mathrm{RD}$ (2004). Inhibition of cancer cell proliferation in vitro by fruit and berry extracts and correlation with antioxidant levels. J Agr Food Chem 52:7264-7271.

Olsson ME, Andersson S, Werlemark G, Uglla M, Gustavsson KE (2005). Carotenoids and phenolics in rose hips. Acta Hort 690:249-252.

Omenn GS, Goodman GE, Thornquist MD, Balmes J, Cullen MR, Glass A, Keogh JP, Meyskens Jr FL, Valanis B, Williams Jr JH, Barnhart S, Hammar S (1996). Effects of a combination of a beta carotene and vitamin $A$ on lung cancer and cardiovascular disease. N Engl J Med 334:1150-1155.

Oprea A (2005). Checklist of vascular plants in Romania. Al.I. Cuza University Ed., Iasi, Romania.

Razungles A, Oszmianski J, Sapis JC (1989). Determination of carotenoids in fruits of Rosa sp. (Rosa canina and Rosa rugosa) and of chokeberry (Aronia melanocarpa). J Food Sci 54:774-775.

Saeed N, Khalillian F, Kiaie FM, Atyeh R, Arabanian A, Chalavi $S$ (2008). Extraction and quantitative determination of ascorbic acid during different maturity stages of Rosa canina L. fruit. J Food Comp Anal 21:300-305.

Saeidi KA, Beygi OR (2009). Determination of phenolics, soluble carbohydrates, carotenoid contents and minerals of dog rose (Rosa canina L.) fruits grown in south-west of Iran. Iran J Med Arom Plants 25:203-215.

Uglla M, Gao X, Werlemark G (2003). Variations among and within dogrose taxa (Rosa sect. caninae) in fruit weight, percentages of fruit flesh and dry matter, and vitamin $\mathrm{C}$ content. Acta Agr Scand BSP 53:147-155.

Uglla M, Gustavsson KE, Olsson ME, Nybom H (2005). Changes in colour and sugar content in rose hips (Rosa dumalis L. and Rosa rubiginosa L.) during ripening. J Hortic Sci Biotech 80:204-208.

Winter K, Apel K, Thamsborg G (2005). A powder made from seeds and shells of a rose-hip subspecies (Rosa canina) reduces symptoms of knee and hip osteoarthritis: a randomized, double-blind, placebo-controlled clinical trial. Scand Rheumatol 34:302-308.

Yoruk IH, Turker M, Kazankaya A, Erez ME, Batta P, Celik F (2008). Fatty acid, sugar and vitamin contents in rose hip species. Asian J Chem 20:1357-1364.

Zanoschi V (2000). The Rosa L. genus, 309-371 p. In: Zanoschi V, Sarbu I, Toniuc A (Eds.). Spontaneous and cultivated woody flora of Romania II, Al. I. Cuza University Ed., Iasi, Romania. 